\title{
ERRATUM
}

M. Fontecave $\cdot$ S. Ollagnier de Choudens

B. Py $\cdot$ F. Barras

\section{Mechanisms of iron-sulfur cluster assembly: the SUF machinery}

Published online: 19 November 2005

(C) SBIC 2005

\section{J Biol Inorg Chem (2005) 10:713-721}

A mistake occurred in the third paragraph under the subheading "The SufA protein". The fourth sentence should read as follows:

The cysteine ligands of a given cluster are exclusively from the $\mathrm{CX}_{\mathrm{n}} \mathrm{CGC}$ sequence and are provided by two polypeptides (the 3 cysteines of the same polypeptide together with the C-terminal cysteine of a second polypeptide).

The online version of the original article can be found at http:// dx.xoi.org/10.1007/s00775-005-0025-1

M. Fontecave $(\square) \cdot$ S. Ollagnier de Choudens Laboratoire de Chimie et Biochimie des Centres Rédox Biologiques, DRDC-CB, CEA/CNRS/Université Joseph Fourier, CEA-Grenoble, UMR 5047, 17 Avenue des Martyrs, 38054 Grenoble Cedex 09, France

B. Py $\cdot$ F. Barras

Laboratoire de Chimie Bactérienne, UPR-CNRS 9043, IBSM,

31 Chemin Joseph Aiguier, 13402 Marseille Cedex 20, France 